\title{
Problems and Suggestions of Students and Teachers Regarding Rawe and Experiential Learning Programme
}

\author{
Shachi Singh and Prabhjot Kaur
}

Dept. of Extension Education P.A.U, Ludhiana, Punjab (141 004), India

\section{Corresponding Author}

Shachi Singh

e-mail: shachisinghs2@gmail.com

\author{
Article History \\ Article ID: AR1861 \\ Received in $10^{\text {th }}$ February, 2018 \\ Received in revised form $18^{\text {th }}$ March, 2018 \\ Accepted in final form $03^{\text {rd }}$ April, 2018
}

\begin{abstract}
The present study was undertaken with the objectives to study the problems of the students and teachers and suggestions given by the students and teachers during village attachment and Experiential Learning Programme. One hundred and fifty students who had undergone RAWE during the year 2014 and 2015 were selected randomly for the study. Data were collected by following distributed questionnaire approach. Findings of the study revealed that majority of the students were having problems regarding less amount of stipend during village attachment. Difficulty in interacting with farmers regarding new technology and their participation in different activities was also perceived as a major problem by the students followed by inadequate materials for field demonstration. Lack of modern equipments and lack of transportation was evident for Experiential Learning Programme I and Experiential Learning Programme II respectively. Irregularity among students and difficulty in arrangement of transportation followed by problems regarding arranging field visits and poor documentation of records by the students were some of the major problems as perceived by the teachers. Provision of adequate and latest materials during visit to village, enhancement in stipend, provision of modern equipments for Experiential Learning Programme I and proper facilities of transportation and accommodation for Experiential Learning Programme II were some of the important suggestions given by the students to make it more effective.
\end{abstract}

Keywords: Problems, suggestions, RAWE, Experiential Learning Programme

\section{Introduction}

The process of learning in the field situation is superimposed on knowledge acquired in the classroom situation. The practical knowledge and experience is being realized the backbone for agricultural development process (Verma et al., 2017). Agricultural education is a significant tool in ensuring increased agricultural productivity, sustainability, environmental and ecological security, profitability, job security and equity (Nanwal and Singh, 2001). Agricultural education is basically aimed to develop skilled manpower to take up farming, undertaking research, teaching and extension work for agricultural development in the Indian context (Kotte and Khare, 2014). The agricultural universities of the country introduced a course of Rural Agricultural Work Experience Programme as the best opportunity, which can orient and equip the required potential among the students of agricultural sciences. Different committees (ICAR Review Committee, 1979; Deans Committee, 1981) recommended for strong linkage of agricultural education with actual farming situation through the programme (Jakhar et al., 2017). Keeping the objective of agricultural universities, Dr. M.S. Swaminathan committees of dean's of SAUs included the RAWE in Agricultural UG programmes (Anonymous 1995). RAWE programme in PAU consisted of 21 days of village attachment, two months of ELP I and one month of ELP II and report writing. Rural Agricultural Work Experience is basically a well organized system with an objective to impart practical training to final year B.Sc. Agriculture students by providing them an opportunity to live and work with the farmers in the villages (Anonymous 1999). On the other hand experiential learning approach is a learner-centered approach and allows an individual student to manage and share responsibility for learning with teachers and farmers. Effective work experience training strategies incorporating rural agricultural experiential learning approach provide opportunities to a student of the final year to engage in fieldwork activity and to review and analyze critically this work experience activity so that they will prove to be useful in their real-life situations (Anonymous, 2011). The students are attached to the research stations of major crops of particular zone and to stay in villages with farm families, agro-based industries, co-operatives NGOs and high-tech cell during different phases of RAWE Programme 
(Anonymous 2013).

\section{Materials and Methods}

The present study was conducted at Punjab Agricultural University (PAU), Ludhiana. A sample of 150 students was randomly selected from the students who had undergone RAWE Programme during the year 2014 and 2015.

\begin{tabular}{lccc}
\hline Year & Number of students & Male & Female \\
\hline 2014 & 66 & 41 & 25 \\
2015 & 84 & 53 & 31 \\
\hline
\end{tabular}

Two teachers from each discipline of College of Agriculture who were associated with RAWE programme were selected. Thus, a sample of 20 teachers was taken for the study. Distributed questionnaire approach was followed to collect the data from the students of Punjab Agricultural University. Data were analyzed with the help of common statistical tools, appropriate to the nature of data and for the purpose of the study.

\section{Results and Discussion}

Results of the study have been discussed under following headings:

\subsection{Problems faced by the students during village attachment}

Whenever any programme is organized, students and teachers face many problems be it transportation, accommodation or any other thing. For taking the response of students regarding various problems related to village attachment, different statements were prepared and the response was taken as yes or no.

Data in the Table 1 revealed that about majority (73\%) of the students faced problem regarding amount of stipend stating that it was not sufficient. Findings of the study are in conformity with those of (Rambabu and Shareef, 1999). Thirty two per cent of the students felt that participation of farmers in different activities were not satisfactory. Twenty seven per cent of the students faced problem regarding materials for field demonstration and only $28 \%$ of the students felt that inadequate transportation facility was a major problem during village attachment.

These findings are in agreement with those of (Kumar and Sharma, 2013). About $25 \%$ of the students faced problems related to stay facilities. The findings are similar with those of (Mahadik et al 2011). Eighty four per cent of the students did not find any problem related to practical exercises. These findings are in contradiction with those of (Kumar and Sharma 2013).About 25 per cent of the students faced problems related to food and refreshment citing the reasons that it was difficult for them to arrange lunch during visits to village and majority of the students that is about $89 \%$ did not face any problem related to time management
Table 1: Distribution of students according to the problems faced by them during Village Attachment $n=150$

\begin{tabular}{|c|c|c|c|}
\hline $\begin{array}{l}\text { Sl. } \\
\text { No. }\end{array}$ & Problems & Yes $f(\%)$ & No $f(\%)$ \\
\hline 1. & $\begin{array}{l}\text { Difficulty in arranging } \\
\text { transport facilities }\end{array}$ & $42(28.00)$ & $108(72.00)$ \\
\hline 2. & $\begin{array}{l}\text { Difficulty in time manage- } \\
\text { ment }\end{array}$ & $17(11.33)$ & $133(88.66)$ \\
\hline 3. & $\begin{array}{l}\text { Difficulty in conducting } \\
\text { practical exercises }\end{array}$ & 24 (16.00) & $126(84.00)$ \\
\hline 4. & $\begin{array}{l}\text { Stay facilities in the village } \\
\text { attachment }\end{array}$ & $37(24.66)$ & $113(75.00)$ \\
\hline 5. & Less amount of stipend & $110(73.33)$ & $40(26.66)$ \\
\hline 6. & $\begin{array}{l}\text { Problems related to food/ } \\
\text { refreshment }\end{array}$ & $38(25.33)$ & $112(74.66)$ \\
\hline 7. & $\begin{array}{l}\text { Inadequate materials for } \\
\text { field demonstration }\end{array}$ & $40(26.66)$ & $\begin{array}{c}110 \\
(73.33 \%)\end{array}$ \\
\hline 8. & $\begin{array}{l}\text { Problems in interacting } \\
\text { with farmers regarding } \\
\text { new technology }\end{array}$ & $41(27.33)$ & $109(72.66)$ \\
\hline 9. & $\begin{array}{l}\text { Problems in Participation } \\
\text { of farmers in different } \\
\text { activities }\end{array}$ & $48(32.00)$ & $102(68.00)$ \\
\hline
\end{tabular}

3.2. Problems faced by the students during Experiential Learning Programme I

For taking the response of students regarding various problems related to Experiential Learning I, different statements were prepared and the response was taken from the students as yes or no.

It can be inferred from the Table 2 that $28 \%$ of the students faced problem regarding lab works, stating that they were not provided latest equipments and materials for proper conduct of lab work while about $85 \%$ of the students did not face any problem related to practical exercises, $21 \%$ of the students

Table 2: Distribution of students according to the problems faced by them during Experiential Learning Programme I $\mathrm{n}=150$

\begin{tabular}{|c|c|c|c|}
\hline $\begin{array}{l}\text { Sl. } \\
\text { No. }\end{array}$ & Problems & Yes f (\%) & No f (\%) \\
\hline 1. & Lack of equipments & $42(28.00)$ & $108(72.00)$ \\
\hline 2. & $\begin{array}{l}\text { Difficulty in conducting } \\
\text { of practical exercises }\end{array}$ & $22(14.66)$ & $128(85.33)$ \\
\hline 3. & $\begin{array}{l}\text { Difficulty in time } \\
\text { management }\end{array}$ & $31(20.66)$ & 119 (79.33) \\
\hline 4. & $\begin{array}{l}\text { Difficulty in maintenance } \\
\text { of records }\end{array}$ & $13(8.66)$ & $137(91.33)$ \\
\hline
\end{tabular}


felt difficulty in time related problems and majority of the students (91\%) perceived that they did not face any difficulty in maintenance of records.

\subsection{Problems faced by the students during Experiential} Learning Programme II

For taking the response of students regarding various problems related to Experiential Learning II, different statements were prepared and the response was taken from the students as yes or no.

Table 3 depicts that majority of the students that is $87 \%$ did not face any problem regarding their visit to different institutes while only $12 \%$ of the students had faced lack

Table 3: Distribution of students according to the problems faced by them during Experiential Learning Programme II $\mathrm{n}=150$

\begin{tabular}{llcc}
\hline $\begin{array}{l}\text { Sl. } \\
\text { No. }\end{array}$ & Problems & Yes $f(\%)$ & No $f(\%)$ \\
\hline 1. & $\begin{array}{l}\text { Difficulty in transpor- } \\
\text { tation, boarding, and } \\
\text { lodging while visiting } \\
\text { the institutes }\end{array}$ & $19(12.66)$ & $131(87.33)$ \\
2. & $\begin{array}{l}\text { Lack of communication } \\
\text { skills while interacting } \\
\text { with extension person- } \\
\text { nel }\end{array}$ & $18(12.00)$ & $132(88.00)$ \\
\hline
\end{tabular}

of communication skills while interacting with extension personnel.

\subsection{Problems faced by the teachers during RAWE and ELP}

Different statements were prepared regarding RAWE, ELP I, ELP II and report writing and response was taken from the teachers as yes or no. (Table 4).

It was revealed that about $50 \%$ of the teachers felt that there was irregularity among the students while $45 \%$ of the teachers perceived that students were not serious. Fifty per cent of the teachers reported difficulty in arrangement of transportation as the major problem during ELP II. Thirty per cent of the teachers reported problems regarding difficulty in arranging field visits and poor documentation maintained by the students. Twenty five per cent of the teachers reported that they had faced difficult in conduct of exercises during Village attachment and ELP I, 15\% of the teachers reported indiscipline and misbehavior of students as major problem and only $25 \%$ of the teachers perceived that there was a lack of coordination/ team work among students. It was observed that $25 \%$ of the teachers faced problems regarding conduct of laboratory work because of lack of equipments and funds. Thirty five per cent of the teachers faced problem regarding poor report writing such as poor quality and language of report stating that it was not up to the mark and most of the students took it casually. Only $15 \%$ and $10 \%$ of the teachers complained
Table: 4 Problems faced by the teachers during conduct of RAWE and ELP $\mathrm{n}=20$

\begin{tabular}{llc}
\hline Sl. & \multicolumn{1}{c}{ Problems } & Yes $\mathrm{f}(\%)$ \\
No. & & \\
\hline 1. & Difficulty in conduct of exercises & 5 \\
2. & Indiscipline among students & 3 \\
3. & Irregularity among students & 10 \\
4. & Non-seriousness among students & 9 \\
5. & Misbehavior of students & 3 \\
6. & Lack of Coordination/Team work & 5 \\
7. & Difficulty in arrangement of transport & 10 \\
8. & Poor documentation maintained by & 6 \\
& the students & \\
9. & Difficulty in arranging field visits & 6 \\
10. & Lack of equipments /funds for lab & 5 \\
& work & \\
12. & Delay in submission of reports & 3 \\
13. & Poor report writing & 7 \\
14. & Delay in presentation of reports & 2 \\
\hline
\end{tabular}

about delaying in submission of reports and presentation of reports respectively.

3.5. Suggestions given by the students to make RAWE and ELP more effective

For village attachment it was suggested by most of the students that adequate and latest materials should be provided during visits to village for demonstration purpose, proper time should be provided for lunch and stipend should be increased.

For Experiential Learning I students suggested that modern equipments should be provided to them to carry out laboratory activities.

Proper facilities of transportation and accommodation and more visits to training centers are few suggestions recommended by students for Experiential Learning Programme II.

3.6. Suggestions given by the teachers to make RAWE and ELP more effective

For village attachment teachers suggested that it should be started at the time of sowing of crops. So that all stages of crop production can be covered, secondly, the responsibility should be allotted to the students in advance so that they shall be well prepared to face the situation in the village and lastly, students should be encouraged to deliver power point presentations.

For Experiential Learning Programme I it was suggested by most of the teachers that more funds should be provided for proper conduct of Laboratory work, more technical staff 
should be provided to execute the programme and proper space should be provided for the students to analyze the soil sample.

Provision of proper transport facilities will help in conducting various outdoor activities efficiently as suggested by the teachers for Experiential Learning Programme II.

\section{Conclusion}

Majority of the students and teachers were satisfied with the modus operandi of RAWE and Experiential Learning Programme on the whole. They did not face any major problem related to this course. However, improper transportation facilities, lack of modern equipments and fewer stipends were some of the problems found to be prevalent among teachers as well as students. Most of the students and teachers suggested for provision of better equipments, proper and timely transportation and accommodation facilities.

\section{Acknowledgement}

The authors acknowledge the students and the teachers of all the departments of college of Agriculture, Punjab Agricultural University, Ludhiana for their immense cooperation and providing us the unbiased data useful for this research.

\section{References}

Anonymous, 1995. The Report of the Third Dean's Committee on Agriculture Education in India, New Delhi: ICAR. Available from https:// www.seea.org.in/vol13-12013/10.pdf.Accessed on May 2016.

Anonymous,1999. Rural Agricultural Work Experience Programme. Manual Acharya N.G. Ranga Agricultural University, Rajendranagar, Hyderabad. Available from https:// www.rseeudaipur.org/wp-content/ uploads/2013/02/331.pdf.Accessed on January 2016.

Anonymous, 2011. Annual report 2011-12. Available from http://www.skuast.org/site/ TemplateHTML/ annualreport/annual-report-11-12.pdf.Accessed on July 2016.

Anonymous, 2013. A-Report-on-Rural-Agricultural-WorkExperience. Available from https://www. scribd.com/ doc/2157396/A-Report-on-Rural-Agricultural-WorkExperience.Accessed in July 2016.
Chauhan, N.B., 2004. Rural Agricultural Work Experience Programme: An appropriate model to create high quality human resources for sustainable extension services. Available from http://agropedia.iitk.ac.in/ openaccess content/rural-agricultural-work-experienceprogramme-rawep-appropriate-model-create-highquality-hu. Accessed in March 2015.

Jakhar, K.C., Joshi, M., Choudhary, B., Kumar, S., 2017. Attitude of Students towards Rural Agriculture Work Experience Programme in Rajasthan State, India. International Journal of Current Microbiology and Applied Sciences 6(7), 4429-4436.

Kotte, S., Khare, N.K., 2014. A Study on Perception among Participants of RAWE programme at J.N.K.V.V. Jabalpur.M.Sc.thesis, Jawaharlal Nehru Krishi Vishwa Vidyalaya, Jabalpur, India.

Kumar, S., Sharma, C., 2013. Outlook of undergraduate students of JNKVV towards RAWE programme. Technofame 2(2), 40-43.

Mahadik, R. P., Mehta, P.G., Sawant, P.A., 2011. Attitude of students towards Rural Work Experience Programme (RWEP). Rajasthan Journal of Extension Education 19(5), 148-51.

Nanwal, R.K., Singh, K.P., 2001. On-farm studies under Rural Agriculture Work Experience (RAWE) education programme in India. Available from onfarm/studies/ under/RuralAgricultureWorkExperience (RAWE)India. Accesssed in March, 2015.

Rambabu, P., Shareef, S.M., 1999. Reaction of students towards rural agricultural work experience programme. Maharashtra Journal of Extension Education 18(7), 279-282.

Singh, R.K., Tyagi, S.K., 2012. Observation of Contact Farmers on Rural Agricultural Work Experience Programme. Indian Research Journal of Extension Education 3(1), 12-15.

Verma, M., Naberia, S., Pyasi, V.K., 2017. Perception of Agriculture Students towards the Rural Agricultural Work Experience (RAWE) Programme. International Journal of Current Microbiology and Applied Sciences 6(8), 3420-3423. 